\title{
ISTIHSAN DAN PEMBARUAN HUKUM ISLAM
}

Salma

\author{
ABSTRAK
}

\section{A. PENDAHULUAN}

Al-Qur'an merupakan sumber ajaran Islam yang telah diturunkan umat manusia sebagai pedoman dalam menata kehidupan di dunia dan di akhirat. Oleh karena itu, maka kandungan Al-Qur'an meliputi seluruh aspek kehidupan manusia. Hanya saja Al-Qur'an dalam membicarakan suatu masalah tidak tersusun secara sistematis dan terperinci. Pada umumnya keterangan Al-Qur'an bersifat global. Kemudian Nabi Muhammad Saw, sebagai utusan Allah untuk hamba-Nya diberikan otoritas untuk menjelaskan lebih rinci hal-hal yang bersifat global yang terdapat dalam Al-Qur'an.

Sunnah sebagai penjelas dari apa yang telah tertulis dalam Alqur'an, maka dapat dipahami bahwa sunnah baik berupa perkataan (qaul), perbuatan ( $\left.f i^{\prime} i l\right)$ dan (taqrir) Nabi merupakan sumber kedua sesudah Al-Qur'an. Namun diakui juga. bahwa Al-Qur'an dan sunnah terbatas, karena tidak semua persoalan dapat dijawab oleh Al-Qur'an dan sunnah. Sementara semakin lama semakin banyak persoalan yang muncul. Untuk menyelesaikan persoalan yang muncul, maka ulama-ulama melakukan ijtihad, ${ }^{1}$ karena wahyu tidak turun lagi sebab Rasulullah telah wafat. Maka tidak ada lagi yang dapat menilai hasil ijtihad mereka apakah benar atau salah, untuk itulah diperlukan ijma' sebagai parameter dalam menguji kebenaran hasil ijtihad itu dengan pertimbangan ijma', yang diambil secara

${ }^{1}$ Hamka Haq, Dialog Pemikiran Islam Ujung Pandang (Cet. I; Ujung Pandang: Yayasan AHKAM, 1997), h. 104. 
kolektif jauh lebih kuat dibanding dengan yang dibuat secara individu. ${ }^{2}$

Kondisi seperti itu tidak dapat lagi dipertahankan, karena kekuasaan Islam semakin luas, dengan terpencarnya para ulama, maka ijma' tidak mungkin dilakukan lagi. Akhirnya masing-masing ulama melakukan istinbath hukum sendiri. Maka lahirlah berbagai macam metode istinbath hukum. Seperti metode qiyas, istihsan, istislah, 'urf, istishab dan lain sebagainya. Metode-metode istinbath hukum seperti itulah yang menjadi obyek pembahasan ushul fikih. ${ }^{3}$

Dalil-dalil syara' yang dijadikan sebagai sumber hukum bagi para mujtahid masing-masing berbeda. Imam Abu Hanifah menjadikan dalil-dalil syara' yaitu: Alqur'an, sunnah, ijma' sahabat, qiyas, istihsan dan 'urf. Mazhab Maliki berpegang kepada Alqur'an, sunnah, ijma' ahlul Madinah, fatwa sahabat, khabar ahad dan qiyas, istihsan, istislah dan sadd al-zara'i, mura'at khilaf almujtahidin, istishab dan syar'u man qablana. Sedangkan dalil-dalil syara' yang dipegang oleh mazhab Syafi'i adalah Alqur'an, sunnah, ijma', qiyas, istislah dan istishab. Bagi Ahmad bin Hanbal berpegang pada Alqur'an, sunnah, fatwa sahabat dan qiyas. ${ }^{4}$

Dari gambaran tersebut, maka dapat dipahami bahwa tidak semua imam mujtahid sepakat menggunakan istihsan sebagai sumber hukum. Imam Syafi'i telah menolak penggunaan istihsan sebagai sumber hukum karena dianggap seorang mujtahid telah mengambil sesuatu yang menurutnya baik, bukan didasari oleh argumentasi yang diperoleh secara langsung menurut redaksi teks (nash) Al-Qur'an dan sunnah ataupun berdasarkan ijma' para sahabat rasul. ${ }^{5}$ Bahkan 1994), h. 5 .

${ }^{2}$ Iskandar Usman, Istihsan dan Pembaharuan Hukum Islam (Cet. I; Jakarta: Raja Grafindo,

${ }^{3}$ Muhammad Abu Zahrah, Ushul al-Fiqh, diterjemahkan oleh Saefullah Ma'sum dengan judul Ushul Fiqih (Cet. VI; Jakarta; Pustaka Firdaus, 2000), h.6.

${ }^{4}$ Iskandar Usman, loc.cit.

${ }^{5}$ Muhammad Abu Zahrah, Imam Syafi'i, Hayatuhu wa'asruhu wa Fiktuhu ara'uhu wa Fiqhuhu, diterjemahkan oleh Abdul Syukur dengan judul, Imam Syafi'i: Biografi dan Pemikirannya dalam Masalah Akidah, Politik dan Figh (Cet. II; Jakarta: Lentera, 2005), h. 479. 
lebih jauh Imam Syafi'i mengatakan menggunakan istihsan sebagai istinbath hukum dengan hawa nafsu dan mencari enaknya saja.

Berdasarkan latar belakang tersebut di atas, maka yang menjadi permasalahan dalam makalah ini adalah sebagai berikut:

1. Bagaimana pengertian, hakikat, pembagian dan kehujjahan istihsan dan bagaimana pula pengertian pembaruan hukum?

2. Bagaimana relevansi antara istihsan dan pembaruan hukum Islam?

\section{B. PEMBAHASAN}

\section{Pengertian Istihsan dan Pembaruan Hukum}

Istihsan secara etimologi merupakan bentuk masdar dari استحسن yang berarti menganggap baik sesuatu. ${ }^{6}$ Atau mengira sesuatu itu baik. ${ }^{7}$ Abu Hanifah tetap menggunakan arti lughawi sebagai dasar pemakaian istihsan yaitu

(astahsin) berarti saya menganggap baik. ${ }^{8}$ Arti lain dari istihsan adalah mengikuti sesuatu yang lebih baik atau mencari yang lebih baik untuk diikuti karena memang disuruh untuk itu. ${ }^{9}$

Dari pengertian secara etimologi tersebut, maka tergambar adanya seseorang yang telah menghadapi dua hal yang keduanya baik, akan tetapi ada hal yang mendorongnya untuk meninggalkan satu di antaranya dan menetapkan untuk diambil yang satunya karena dianggap lebih baik untuk diamalkan.

Adapun pengertian istihsan menurut istilah, ada beberapa definisi yang dirumuskan oleh beberapa ahli ushul:

${ }^{6}$ Umar Hubeis dan A. Yazid, Fiqh al-Lighah al-“Arabiyah, Jilid II (Cet. IX; Surabaya; Pustaka Progresif, 1985), h. 187.

${ }^{7}$ Badran Abu al-'Ainaini Badran, Ushul Fiqh al-Islamiy (Mesir: Mu'assasah Syabab alIskandariyah, t.th), h. 263.

${ }^{8}$ Abu Zahrah, Ushul, op.cit., h. 402.

${ }^{9}$ Amir Syarifuddin, Ushul Fiqh, Jilid II (Cet. I; Jakarta: Logos, 1999), h. 305. 
1. Ibnu Subki mengajukan dua rumusan definisi, yaitu:

$$
\text { عدول عن قيا س الي قياس اقو ي منه }
$$

Beralih dari penggunaan suatu qiyas kepada qiyas lain yang lebih kuat dari padanya. (qiyas pertama). ${ }^{10}$

$$
\text { عد و ل عن الد ليل الي العادة للمصلحة }
$$

Beralih dari penggunaan sebuah dalil kepada adat kebiasaan karena suatu kemaslahatan.

Ibnu Subki menjelaskan bahwa definisi yang pertama tidak terjadi perdebatan karena yang terkuat di antara dua qiyas harus didahulukan. Sedangkan definisi kedua ada pihak yang menolaknya. Alasannya, apabila dapat dipastikan bahwa adat istiadat itu baik karena berlaku seperti pada masa Nabi atau sesudahnya, dan tanpa ada penolakan dari nabi atau dari yang lainnya, tentu ada dalil pendukungnya, baik dalam bentuk nash maupun ijma'. Dalam bentuk seperti ini adat harus diamalkan secara pasti. Namun bila tidak terbukti kebenarannya, maka cara tersebut tertolak secara pasti. ${ }^{11}$

2. Istilah istihsan dikalangan Ulama Hanafiyah sebagaimana yang dikutip oleh al-Sarkhasi ${ }^{12}$

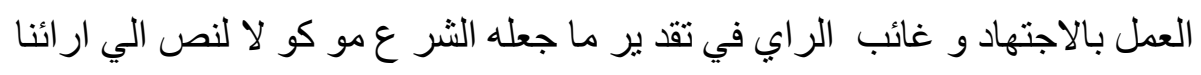

Beramal dengan ijtihad dan umum pendapat dalam menentukan sesuatu yang syara' menyerahkannya kepada kita.

الد ليل الذي يكو ن معا رضـا للقياس الظا هر الذي تسبق اليه الاوهام قبل انعام التا مل في حكم العا د ة واشبا هها من الا صول يظهر هن الد ليل الذي عارضه فوقه في القوة فان العمل به هو الو ا

Dalil yang menyalahi qiyas yang zahir yang didahului prasangka sebelum

${ }^{10}$ Ibid.

${ }^{11}$ Ibid.

${ }^{12}$ Ibid., h. 307. 
diadakan pendalaman terhadap dalil itu namun setelah diadakan penelitian yang mendalam terhadap dalil itu dalam hukum yang berlaku dan dasar-dasar yang sama dengan itu ternyata bahwa dalil yang menyalahi qiyas itu lebih kuat dan oleh karenanya wajib diamalkan.

3. Istihsan menurut ulama Malikiyah di antaranya sebagaimana yang dikemukakan oleh oleh al-Syatibi. ${ }^{13}$

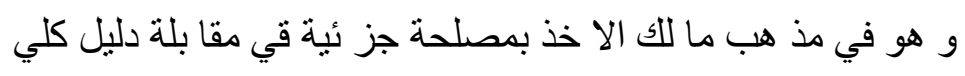

lstihsan dalam Mazhab Malik adalah menggunakan kemaslahatan yang bersifat $j u z^{\prime} i$ sebagai pengganti dalil yang bersifat $k u l l i$.

Dari definisi di atas mengandung arti bahwa seorang mujtahid semestinya menetapkan hukum dengan berpedoman kepada dalil yang ada yang bersifat umum. Namun karena dalam keadaan tertentu mujtahid melihat karena adanya kemaslahatan yang bersifat khusus, maka dalam menetapkan hukum tidak berpedoman kepada dalil umum yang ada, tetapi menggunakan kemaslahatan atau kepentingan yang bersifat khusus.

Dari beberapa definisi yang telah dikemukakan oleh ulama, maka dapat ditemukan esensi istihsan ada dua: ${ }^{14}$

1. Mentarjih qiyas khafi daripada qiyas jali karena ada dalil yang mendukungnya.

2. Memberlakukan pengecualian hukum juz'iyah daripada hukum kulli atau kaidah umum, didasarkan pada dalil khusus yang mendukungnya.

Meskipun definisi di atas cukup beragam, namun ada kesamaankesamaan yang dapat kita tarik benang merah, bahwa istihsan adalah meninggalkan suatu hukum yang telah ditetapkan oleh syara' dan menetapkan hukum lain karena ada dalil yang lebih cocok dan lebih kuat menurut jiwa orang yang melakukan ijtihad. Baik dengan cara meninggalkan qiyas jali dan mengambil qiyas khafi sebagai sandaran hukum, atau menetapkan suatu hukum dengan cara mengambil permasalahan yang sifatnya $j u z ' i$

\footnotetext{
${ }^{13}$ Abi Ishaq al-Syatibi, al-Muwafaqat fi Ushul al-Syari'ah, Juz I (Cairo: t.th), h. 30.

${ }^{14}$ Nasroen Harun, Ushul Fiqh I (Cet. I; Jakarta: Loogos, 1996), h. 105.
} 
dari permasalahan yang sifatnya kulli. Oleh karena itu jelaslah bahwa istihsan tetap dibangun berdasarkan dalil-dalil yang kuat, bukan berdasarkan hawa nafsu belaka. Sedangkan definisi pembaharuan seperti dalam literatur kontemporer, kata "pembaruan" silih berganti dipergunakan dengan kata reformasi, modernisasi, reaktualisasi, dekonstruksi, tarjih, islah dan tajdid. Di antara kata-kata tersebut yang paling sering digunakan adalah kata reformasi, islah dan tajdid. Reformasi berasal dari Bahasa Inggris "reformation" yang berarti membentuk atau menyusun kembali. ${ }^{15}$ Reformasi sama artinya dengan memperbarui, asal kata "baru" dengan arti memperbaiki supaya menjadi baru atau mengganti dengan yang baru, menggantikan atau menjadikan baru, atau proses perbuatan, cara memperbarui, proses pembangunan adat istiadat atau cara hidup yang baru. ${ }^{16}$ Tajdid mengandung arti membangun kembali, menghidupkan kembali, menyusun kembali atau memperbaiki agar dapat dipergunakan sebagaimana yang diharapkan. ${ }^{17}$ Sedangkan kata islah mengandung arti perbaikan atau memperbaiki. ${ }^{18}$ Dalam sejarah perkembangan pemikiran Islam kata islah dan tajdid sering dipakai secara berdampingan dengan arti yang sama adalah "pembaruan. ${ }^{19}$ Bustami Muhammad Saad ${ }^{20}$ mengemukakan bahwa kata tajdid adalah lebih tepat digunakan untuk membahas tentang pembaruan hukum, sebab kata tajdid mempunyai arti pembaruan. Sedangkan kata islah meskipun sering digunakan secara berdampingan tetapi lebih dekat pengertiannya kepada "pemurnian".

${ }^{15}$ John M. Echol dan Hassan Shadily, Kamus Inggeris Indonesia (Cet. XXV; Jakarta; Gramedia, 2000), h. 473.

${ }^{16}$ Departemen Pendidikan Nasional, Kamus Besar Bahasa Indonesia, Edisi Keempat (Cet. II; Jakarta; Balai Pustaka, 2002), h. 109.

${ }^{17}$ Mahmud Yunus, Kamus Arab Indonesia (Jakarta: Yayasan Penyelenggara Penterjemah Alquran, 1990), h. 84.

${ }^{18}$ Ibid., h. 219

146.

${ }^{19}$ Abdul Manan, Reformasi Hukum Islam di Indonesia (Cet. I; Jakarta: Raja Grafindo, 2007), h.

${ }^{20} \mathrm{Ibid}$. 


\section{Hakikat Istihsan}

Para ulama fikih berbeda pendapat mengenai keabsahan istihsan sebagai dalil pokok dalam pengambilan hukum. Di antara ulama yang paling santer dalam membela dan mengamalkan istihsan sebagai hujjah adalah ulama Mazhab Hanafi. Di tambah sebagian ulama-ulama lainnya dari Madzhab Maliki dan Hanbali. Hanya saja, ulama Mazhab Syafi'i memiliki pandangan yang berbeda dalam memposisikan istihsan sebagai dalil pokok dalam pengambilan hukum.

Sebenarnya tidak ada perbedaan yang signifikan antara pandangan ulama yang membela dan mendukung istihsan dengan ulama yang menentang istihsan. Mereka tidak berselisih dalam penggunaan lafaz istihsan, karena kata yang mengandung makna hasan (baik) itu terdapat dalam teks Al-qur'an dan sunnah. Allah Swt berfirman dalam QS. Al-Zumar (39) : 17-18.

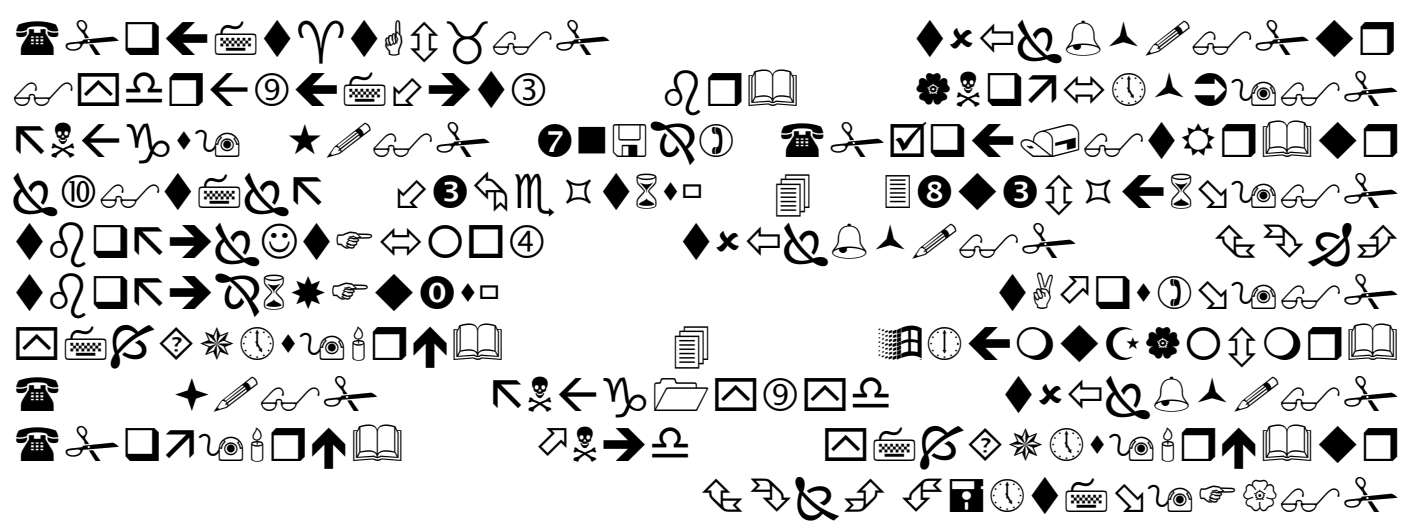

Terjemahnya: "Dan orang-orang yang menjauhi thaghut (yaitu) tidak menyembahnya dan kembali kepada Allah, bagi mereka berita gembira; sebab itu sampaikanlah berita itu kepada hamba-hamba-Ku. Yang mendengarkan perkataan latu mengikuti apa yang paling baik di antaranya. Mereka itulah orang-orang yang telah diberi Allah petunjuk dan mereka itulah orangorang yang mempunyai akal." 21

Selain itu juga, Rasulullah Saw, bersabda:

\footnotetext{
${ }^{21}$ Departemen Agama RI, Al-Qur'an dan Terjemahnya (Semarang: Toha Putra, 2002), h.. 661.
} 


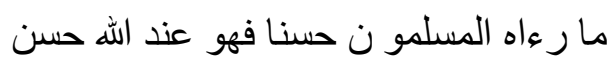

Artinya : "Sesuatu yang dipandang oleh kaum muslimin itu baik, maka menurut Allah pun adalah baik. (HR. Ahmad).

Dari sini, ulama Mazhab Hanafi tetap berpegang kepada istihsan. Akan tetapi mereka menggunakannya tetap berdasarkan kepada dalil-dalil yang kuat. Bukan kepada hawa nafsu sebagaimana yang dituduhkan para ulama yang menentang istihsan. Mereka berpendapat dalam posisi istihsan ini, melakukan istihsan lebih utama dari pada melakukan qiyas. Karena pengambilan dalil yang lebih kuat diutamakan dari pada dalil yang lemah. Pada dasarnya dalam praktek istihsan ini, tidak mesti ada dalil yang bertentangan, tetapi istihsan itu cukup dilakukan ketika ada dalil yang lebih kuat, sekaligus menggugurkan dalil yang lemah. Atau istihsan itu dilakukan dengan cara meninggalkan qiyas karena ada dalil-dalil lain yang lebih kuat yang diambil dari teks Al-Qur'an, sunnah, ijma', adanya darurat, atau dari qiyas khafi.

\section{Pembagian Istihsan}

Abdul Karim Zaidan dalam bukunya Al-Wajiz fi Ushul Fiqh, membagi istihsan kepada dua segi. Pertama, istihsan dipandang dari segi pemindahan hukumnya, yang kedua, istihsan dipandang dari sandaran dalilnya. ${ }^{22}$ Adapun istihsan dari segi pemindahan hukumnya, terbagi kepada dua macam yaitu sebagai berikut:

1. Istihsan dengan cara pemindahan hukum kulli kepada hukum juz'i. Contohnya, dalam hukum syara' seseorang tidak boleh melakukan transaksi jual beli dengan barang yang belum ada ketika dilangsungkannya akad jual beli. Aturan ini berlaku untuk seluruh jenis transaksi jual beli. Karena jual beli tanpa adanya barang ketika akad berlangsung maka akad tersebut menjadi rusak. Inilah yang disebut

${ }^{22}$ Abdul Karim Zaidan, Al-Wajiz fi Ushul Fiqhi ( Beirut: Mu'assasah Risalah, 2002), h.. 230. 
dengan hukum kulli.

Kemudian, syari'at memberikan keringanan dan pengecualian kepada pembelian barang dengan uang tunai tapi barangnya dikirim kemudian dengan waktu dan jenis barang yang telah ditentukan (jual-beli salam). Jual beli ini dilakukan karena telah menjadi kebiasaan di masyarakat, juga jual beli ini untuk mempermudah bagi para penjual yang tidak memiliki modal. Pengecualian atau keringanan ini dinamakan dengan pemindahan hukum kulli kepada hukum juz'i. Mengenai jual beli salam ini Rasulullah Saw, bersabda:

من اسلف في شيئ فليسلف في كيل معلو م ووزن معلو م الي اجل معلو م ( رواه البخاري)

Artinya: "Barang siapa yang meminjamkan sesuatu, hendaknya ia meminjamkan dengan takaran yang jelas, timbangan yang jelas dan dalam tempo yang jelas." (HR. Bukhari).

2. Istihsan dengan cara pemindahan dari qiyas jali kepada qiyas khafi, karena ada dalil yang mengharuskan pemindahan itu. Contoh, menurut Mazhab Hanafi, sisa minum burung buas seperti burung elang dan gagak adalah suci dan halal diminum. Penghalalan ini ditetapkan berdasarkan istihsan. Menurut qiyas jali, meminum sisa minuman binatang buas seperti anjing dan burung buas adalah haram, karena binatang tersebut langsung minum dengan lisannya yang diqiyaskan kepada dagingnya. Menurut istihsan, berbeda antara mulut binatang buas dengan burung buas tadi. Kalau binatang buas langsung minum dengan mulutnya, sedangkan burung buas minum melalui paruhnya yang bukan merupakan najis. Karena itu mulut burung buas tadi tidak bertemu dengan dagingnya yang haram dimakan. Dari perbedaan antara binatang buas dan burung buas, maka ditetapkanlah perpindahan qiyas jali kepada qiyas khafi. 
Sedangkan istihsan dipandang dari seqi sandaran dalilnya, dibagi menjadi beberapa macam yaitu:

1. Istihsan yang disandarkan kepada teks Al-qur'an atau hadits yang lebih kuat. Seperti jual beli salam yang telah penulis bahas.

2. Istihsan yang disandarkan kepada ijma'. Contoh, bolehnya mengambil upah dari orang yang masuk WC. Menurut kaidah umum, tidak boleh seseorang mengambil upah tersebut, karena tidak bisa diketahui dan dipastikan berapa lama si pengguna berada di dalam WC, juga tidak bisa diketahui seberapa banyak dia menggunakan air di dalam WC. Tetapi berdasarkan istihsan, diperbolehkan si petugas mengambil upah dari pengguna WC tersebut, karena sudah membantu menghilangkan kesulitan orang, juga sudah menjadi kebiasaan dan tidak ada penolakan dari seorang pun sehingga menjadi ijma'.

3 .Istihsan yang disandarkan kepada adat kebiasaan ('urf). Seperti pendapat sebagian ulama yang membolehkan wakaf dengan barang-barang yang bergerak, seperti mewakafkan buku, mobil dan barang-barang lainnya. Menurut kaidah umum, wakaf itu harus pada barang-barang yang tidak bergerak, seperti tanah, atau bangunan. Kemudian ulama membolehkan wakaf dengan barang-barang yang bergerak tadi karena sudah menjadi adat ('urf) di lingkungan tersebut.

4. Istihsan yang disandarkan kepada urusan yang sangat darurat._Seperti, membersihkan sumur yang terkena najis, hanya dengan mengambil sebagian air dari sumur itu. Menurut qiyas, air sumur tersebut tidak bisa dibersihkan lagi, karena alat untuk membersihkan air itu sudah kena najis, dan tidak mungkin dibersihkan. Tetapi menurut istihsan, air itu bersih lagi hanya dengan mengeluarkan sebagian airnya saja. Karena mengeluarkan sebagian air itu tidak mempengaruhi kesucian sisanya. Inilah yang dinamakan 
dengan darurat, yang bertujuan untuk memudahkan urusan manusia. Selain itu juga dalam ayat Alqur'an sudah disebutkan bahwa agama itu bukan untuk menyusahkan manusia. Allah Swt berfiman dalam QS. Al-Hajj (22) $: 78$

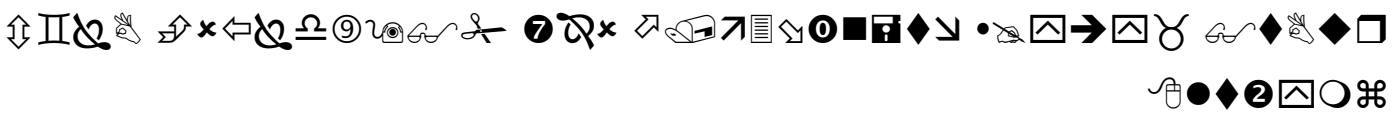
Terjemahnya : "Dia sekali-kali tidak menjadikan untuk kamu dalam agama suatu kesempitan."23

5. Istihsan yang disandarkan kepada kepada kemaslahatan.

6. Istihsan yang disandarkan kepada qiyas khafi. Seperti bolehnya minum air sisa minum burung buas seperti elang dan gagak.

\section{Kehujjahan Istihsan}

Para ulama yang menggunakan istihsan, adalah Imam Abu Hanifah, Imam Malik dan sebagian pengikut Imam Ahmad bin Hanbal. Alasan-alasan mereka adalah, penelitian terhadap beberapa peristiwa hukum dan ketentuan hukumnya membuktikan bahwa terus menerusnya berlaku ketetapan qiyas, berkelanjutannya ketetapan umum dan meyeluruhnya ketetapan kulli, kadang-kadang membawa hilangnya maslahat dan akan membawa mafsadat. ${ }^{24}$ Oleh karenanya merupakan suatu rahmat Allah, karena telah dibuka peluang bagi mujtahid untuk memindahkan peristiwa hukum dari ketentuan qiyas kepada ketentuan hukum lain yang dapat mewujudkan maslahat dan menolak mafsadat.

${ }^{23}$ Al-Qur'an dan Terjemahnya, op.cit., h. 474.

${ }^{24}$ Ahmad Hassan, Islamic Reserch Institute, diterjemahkan oleh Aqah Garnadi dengan judul Pintu Ijtihad sebelum Tertutup (Cet. I; Bandung: Pustaka, 1984), h. 141. 
Menurut al-Syatibi, istihsan yang telah dipakai oleh imam mazhab bukanlah semata-mata didasarkan pada logika murni dan mengikuti hawa nafsu, tetapi sebenarnya semuanya dikembalikan kepada maksud syara' yang umum dalam peristiwa-peristiwa yang dikemukakan yang sifatnya kontekstual demi terwujudnya "maqashid al-syari'ah. ${ }^{25}$ Sebagai contoh dibolehkannya memeriksa aurat tubuh untuk kesehatan. Ini merupakan pengecualian dari kaidah umum yang mengharamkannya.

Husain Hamid Hassan menjelaskan bahwa dasar pemakaian istihsan menurut Imam Malik, kembali kepada nash dari dua segi: ${ }^{26}$ Pertama, kaedah istihsan merupakan kaedah yang diambil dari dalil syara' dengan cara induksi yang memberi faedah qath'i, bukan mengemukakan pendapat akal atau mengikuti hawa nafsu semata. Kedua, kaedah istihsan mujtahid kembali kepada dalil syara' yang diambil dari induksi nash-nash syariat. Ijma' dan 'urf telah diakui kehujjahannya oleh nash syariat. Sedangkan maslahah mursalah bila dihadapkan dengan qiyas berarti beramal dengan nash-nash yang mendukung maslahat daripada qiyas.

Demikian pula Mazhab Hanafi memberi penjelasan tentang istihsan tidak berbeda dengan Mazhab Malik. Al-Taftazani mengemukakan bahwa istihsan merupakan suatu dalil-dalil yang disepakati oleh para ulama karena istihsan di dasarkan kepada nash, ijma' darurat atau kepada qiyas khafi. ${ }^{27}$

Adapun dalil-dalil yang digunakan Mazhab Hanafi dalam pemakaian istihsan adalah firman Allah SWT dalam QS. Az-Zumar (39) : 18 dan 55.

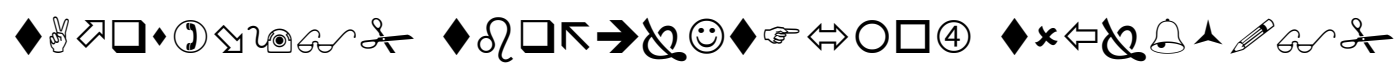

${ }^{25}$ Abi Ishaq al-Syatibi, Juz IV, op.cit., h. 206.

${ }^{26}$ Husain Hamid Hasan, Nazriyat al-Maslahat fi al-Fiqh al-Islamiyah ( Mesir: Dar al-Wahdat al'Arabiyah, t.th), h. 589. 62.

${ }^{27}$ Al-Taftazani, Syarh al-Talwik 'ala al-Taudih, Juz II (Beirut: Dar al-Kutub al-Ilmiyah, t.th), h. 


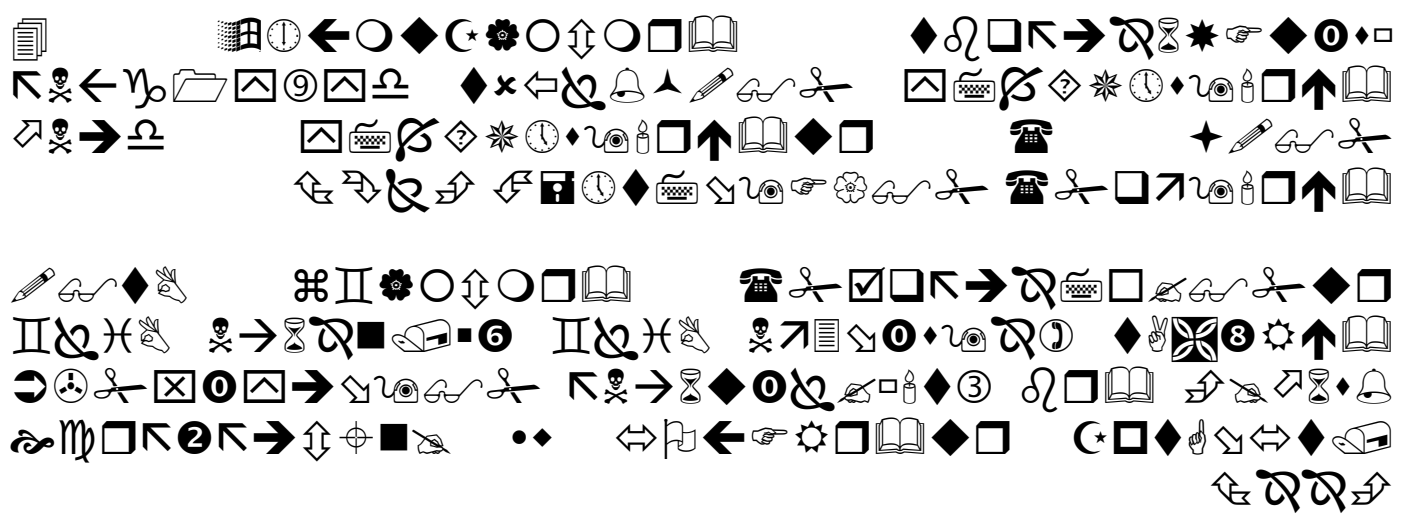

Ayat pertama menurut mereka adalah memuji orang-orang yang mengikuti pendapat yang paling baik, sedang ayat kedua memerintahkan untuk mengikuti yang paling baik apa yang diturunkan oleh Allah. ${ }^{28}$ Seandainya mengikuti cara yang terbaik namun tidak mempunyai kekuatan dalil, tentu Allah tidak mengisyaratkan seperti itu. Hal ini menunjukkan bahwa istihsan tidak lain adalah upaya untuk membuat yang terbaik itu diakui kekuatannya dalam agama.

Selain ayat tersebut, para ulama juga. menggunakan ijma' sebagai dasar kehujjahan istihsan. Sebagai contoh, bolehnya masuk ke dalam kolam renang tanpa ada penetapan harga tertentu, penggantian air yang digunakan dan jangka waktu pemakaiannya.

Imam Syafi'i beserta pengikutnya memiliki pandangan yang berbeda mengenai istihsan. Mereka menolak dan mengkritik habis orang-orang yang menggunakan istihsan sebagai dalil pokok dalam pengambilan hukum setelah empat dasar pokok yang telah disepakati yaitu Al-Qur'an, Hadits, ijma', dan qiyas. Bahkan mengenai istihsan ini, Imam Syafi'i berkata : من استحسن فقد شر ع artinya : "Barangsiapa yang berhujjah dengan

\footnotetext{
${ }^{28}$ Amir Syarifuddin, op.cit., h. 317.

${ }^{29}$ Imam Syafi'I, Al-Risalah, diterjemahkan oleh Ahmadi Toha (Cet. I; Jakarta: Pustaka Firdaus, 1986), h. 241
} 
istihsan berarti ia telah menetapkan sendiri hukum syara'.

Imam Syafi'i berkeyakinan bahwa berhujjah dengan istihsan, berarti dia telah mengikuti hawa nafsunya, karena telah menentukan syariat baru. Sedangkan yang berhak membuat syariat itu hanyalah Allah Swt. Dari sinilah terlihat, bahwa Imam Syafi'i beserta pengikutnya cukup keras dalam menolak masalah istihsan. ${ }^{30}$

Dilihat dari paradigma yang dipakai oleh Imam Syafi'i berserta pengikutnya, ternyata berbeda dengan paradigma yang dipakai oleh Ulama Hanafiyah. Imam Syafi'i berpegang bahwa yang berhujjah dengan istihsan berarti ia telah mengikuti hawa nafsunya. sedangkan istihsan yang dimaksud oleh ulama Hanafiyah adalah berhujjah berdasarkan dalil yang lebih kuat.

Adapun dalil-dalil yang disodorkan ulama Hanafiyah mengenai istihsan, seperti kutipan ayat Al-Qur'an dalam surat az-Zumar ayat 18, dan hadits Rasulullah Saw, yang diriwayatkan oleh Imam Ahmad, ulama Syafi'iyah memiliki pemahaman yang berbeda juga. ${ }^{31}$

Mengenai Surah az-Zumar ayat 18 tersebut, ulama Syafi'i menjawab bahwa ayat tersebut tidak menunjukan adanya istihsan. Juga tidak menunjukan wajibnya mengikuti perkataan yang paling baik. Kemudian mengenai kutipan hadis Rasulullah Saw., mereka menjawab bahwa hadits tersebut mengisyaratkan adanya ijma' kaum muslimin. Sedangkan ijma' itu merupakan hujjah yang

\footnotetext{
${ }^{30} \mathrm{Abu}$ Zahrah, Ushul, op.cit., h. 415.
}

\footnotetext{
${ }^{31}$ Abdul Karim Zaidan, op.cit., h. 234.
} 
bersumber kepada dalil. ${ }^{32}$ Jadi hadis tersebut tidak berarti setiap orang yang memandang suatu urusan itu baik, maka baik menurut Allah Swt. Kalau pemahamannya seperti yang dilontarkan ulama Hanafiyah, maka ketika kaum muslimin yang awwam memandang suatu perkara itu baik, maka baik pula menurut Allah Swt. Inilah pemahaman yang seharusnya tidak ada dalam benak kaum muslimin.

Jadi penolakan Syafi'iyah tersebut bukan pada lafaz istihsannya, karena Imam Syafi'i pun sering menggunakan kata-kata istihsan. Seperti pada kasus pemberian mut'ah kepada wanita yang di talak. Imam Syafi'i berkata aku menganggap baik pemberian nilai mut'ah itu sebanyak 30 dirham. Padahal di dalam teks Al-Qur'an tidak ada penentuan nilai yang harus diberikan. Tetapi beliau melakukan itu sebagai ijtihad beliau atas makna pemberian yang ma'ruf. Jadi, cara seperti ini sebenarnya menurut Hanafiyah merupakan c ara pengambilan hukum dengan istihsan, tetapi menurut Syafi'i, ini bukan dengan cara istihsan tetapi dengan membatasi sesuatu dengan melihat kondisi waktu itu (takhshishul illah) ${ }^{33}$

\section{B. Relevansi istihsan dengan pembaruan hukum Islam.}

Setelah menyimak pengertian istihsan dan pembaruan hukum di atas, dan untuk melihat lebih jauh lagi relevansi istihsan dengan pembaruan hukum Islam, maka perlu ditegaskan kembali bahwa pembaruan hukum Islam berarti menetapkan hukum yang mampu menjawab permasalahan dan perkembangan baru yang ditimbulkan oleh kemajuan ilmu pengetahuan dan teknologi modern, baik menetapkan hukum terhadap

\footnotetext{
${ }^{32}$ Imam Syafi'i, op.cit., h. 242.

${ }^{33}$ Abuddin Nata, Masail Fiqhiyah (Cet. I; Jakarta: Kencana, 2003), h. 162.
} 
masalah baru untuk menggantikan ketentuan hukum lama yang tidak sesuai lagi dengan keadaan kemaslahatan manusia masa sekarang. ${ }^{34} \quad$ Muhammmad Rasyid Ridha mengatakan ${ }^{35}$ bahwa sesungguhnya hukum itu dapat berbeda karena ada perbedaan waktu dan lingkungan, situasi dan kondisi. Jika satu hukum yang diundangkan pada waktu dibuat sangat dibutuhkan oleh masyarakat terhadap hukum itu, tetapi kemudian kebutuhan akan hukum itu sudah tidak ada lagi, maka sebaiknya hukum yang baru sesuai dengan situasi dan kondisi, waktu dan tempat dalam masyarakat yang melaksanakan hukum itu.

Adanya faktor-faktor penyebab terjadinya pembaruan hukum Islam sebagimana tersebut di atas, yang mengakibatkan munculnya berbagai macam perubahan dalam tatanan sosial umat Islam, baik yang menyangkut ideologi politik, sosial, budaya, dan sebagainya. ${ }^{36}$. Faktor-faktor tersebut melahirkan sejumlah tantangan baru yang harus dijawab sebagai bagian yang tidak terpisahkan dari upaya pembaruan pemikiran hukum Islam. Untuk mengantisipasi masalah ini, maka ijtihad tidak boleh berhenti dan harus terus menerus dilaksanakan untuk mencari solusi terhadap berbagai masalah hukum baru yang sangat diperlukan oleh umat Islam.

Ilmu pengetahuan dan teknologi modern telah mendapat perhatian yang serius dalam Islam. Karena Islam sendiri sangat menginginkan umatnya untuk menuntut ilmu pengetahuan dan menguasai teknologi. Keinginan itu dapat dipahami dari Al-Qur'an dan sunnah Nabi Saw,. Seperti firman Allah SWT dalam QS. Al-'Alaq (96) : 1-5.

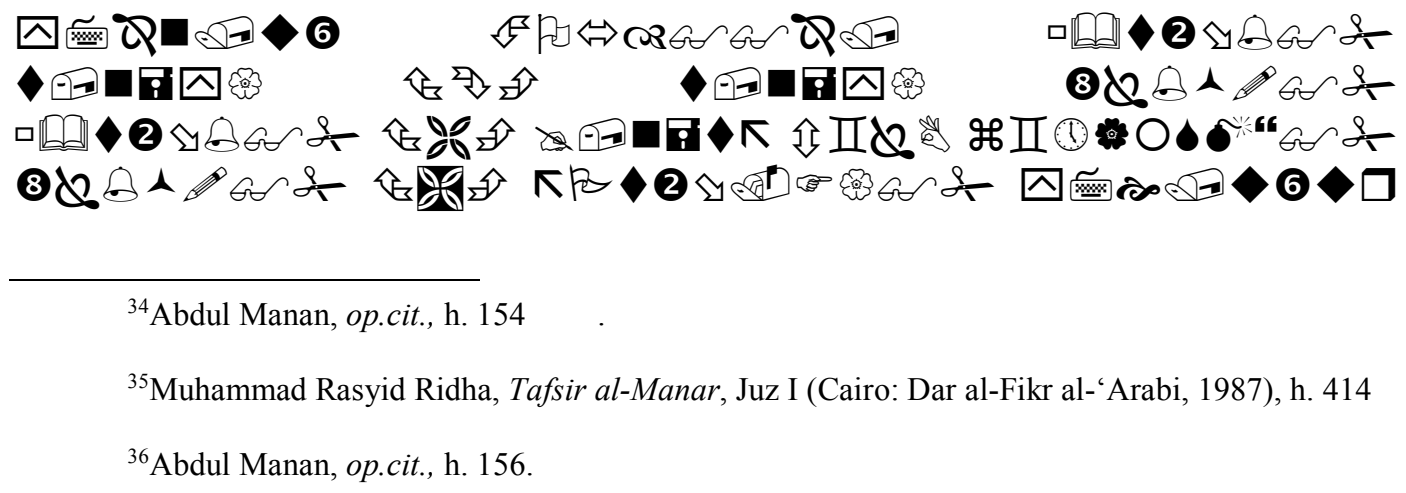




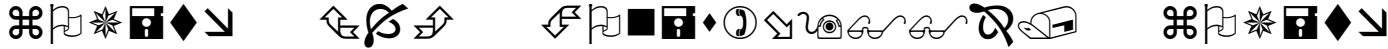

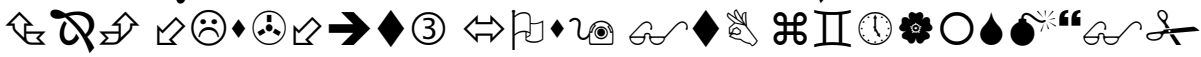
Terjemahnya : “ 1. Bacalah dengan (menyebut) nama Tuhanmu Yang menciptakan, 2. Dia telah menciptakan manusia dari segumpal darah, 3. Bacalah, dan Tuhanmulah Yang Maha Pemurah, 4. Yang mengajar (manusia) dengan perantaraan kalam. 5. Dia mengajarkan kepada manusia apa yang tidak diketahuinya." 37

Di samping ayat di atas, terdapat ayat lain yang menyarankan untuk menuntut ilmu seperti: QS. at-Taubah (9) : 122, QS. al-Ghasyiyat (88) : 17-20, dan QS.al-Mujadilat (58): 11. Serta hadis yang menganjurkan umatnya untuk menuntut ilmu adalah:

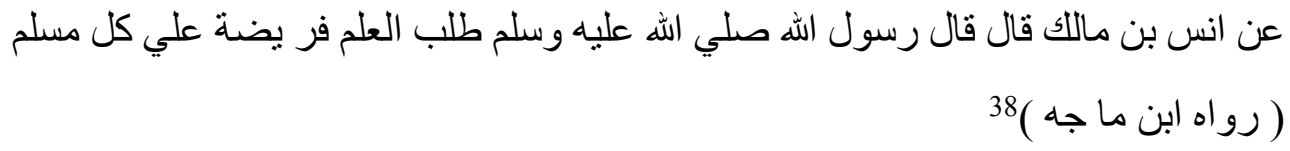

Artinya :

"Dari Anas bin Malik berkata: Rasulullah saw, bersabda menuntut ilmu merupakan fardhu bagi setiap muslim.” (HR.Ibnu Majah)

Dari ayat-ayat dan hadis tersebut, maka dapat dipahami bahwa Islam tidak menghambat perkembangan ilmu pengetahuan dan teknologi, bahkan sebaliknya Islam sangat mendorong umatnya untuk menguasai ilmu pengetahuan dan teknologi. Bahkan dengan penguasaan ilmu pengetahuan dan teknologi manusia dapat mengatur dan mengelola alam ini dengan baik.

Kemajuan ilmu pengetahuan dan teknologi itu telah menimbulkan perkembangan baru dalam segala bidang kehidupan, tidak terkecuali bidang hukum Islam. Seiring dengan perkembangan ilmu pengetahuan dan teknologi telah mendapat tempat terhormat dalam Islam, maka agar hukum Islam tidak ketinggalan zaman dan mampu menjawab perkembangan baru yang timbul dalam masyarakat. Maka

\footnotetext{
${ }^{37}$ Departemen Agama RI, op.cit., h.904.

${ }^{38} \mathrm{CD}$ Rom, al-Kutub al-Tis'ah
} 
perkembangan baru itu harus dijadikan pertimbangan dalam penetapan hukum.

Agama Islam telah memuliakan dan menghormati manusia sejak lahir sampai meninggal. Maka anggota badan manusia merupakan pemberian dari Allah SWT, kepada manusia agar mereka dapat merealisasikan tuntutan-Nya dengan sempuma, yaitu tuntutan untuk mengabdi kepada-Nya. Oleh karena itu Islam melarang memotong dan mengambil anggota tubuh manusia tersebut meskipun ia telah meninggal. ${ }^{39}$ Sebagaimana Hadis Nabi Saw., berbunyi:

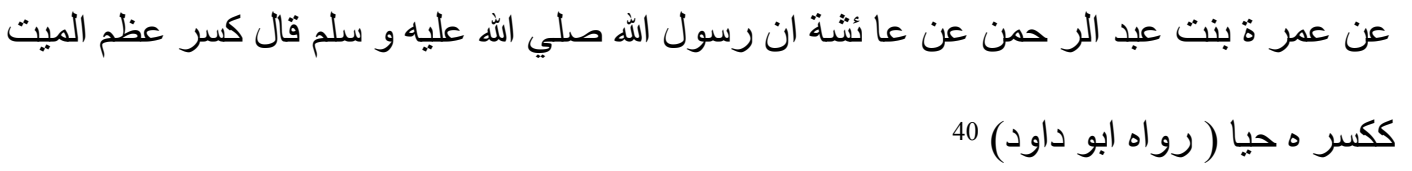

\section{Artinya:}

"Dari 'Amrah binti Abdi Rahman dari 'Aisyah sesungguhnya Rasulullah saw., bersabda: memecahkan tulang orang mati sama hukumnya dengan memecahkan tulangnya ketika ia hidup”. (Diriwayatkan oleh Abu Dawud).

Akibat kemajuan ilmu pengetahuan dan teknologi dalam bidang kedokteran sehingga memungkinkan dilakukannya pencangkokan kornea mata, bagi yang sudah meninggal secara yuridis dan medis, hukumnya mubah. ${ }^{41}$ Lalu bagaimana pandangan Islam terhadap pencangkokan kornea mata bagi si mayat kepada orang buta yang sangat membutuhkan agar ia dapat melihat seperti orang normal lainnya.

Transplantasi ini khususnya kornea mata dibenarkan menurut Islam, dengan pertimbangan bahwa bagi donor yang telah meninggal korneanya tidak berfungsi dan tidak bermanfaat lagi baginya. Padahal, jika korneanya dimanfaatkan oleh tunanetra akan sangat besar manfaatnya. Meskipun si tunanetra tidak akan meninggal karena tidak dapat melihat, namun penglihatan merupakan kebutuhan hidup, untuk menghindari kesempatan dan akan bisa menyempurnakan fungsi hidup si

\footnotetext{
${ }^{39}$ Iskandar Usman, op.cit., h. 180.

${ }^{40}$ CD Rom, al-Kutub al-Tis'ah

${ }^{41}$ Abuddin Nata, op.cit., h. 106.
} 
tunanetra setelah dapat melihat dengan jalan transplantasi kornea mata orang lain. Allah tidak menjadikan kesempitan bagi umat manusia dalam beragama. Kebutuhan yang diperlukan untuk menghindari kesempatan hidup dapat diberi kedudukan darurat, baik bersifat khusus maupun umum. ${ }^{42}$

Memuliakan anggota tubuh si mayat merupakan masalah tahsiniyat tidak perlu dipertahankan, bila dengan mempertahankan maslahat tahsiniyat dapat menyebabkan lenyapnya maslahat yang lebih utama yaitu hajiyat dan daruriyat Sedangkan kebolehan pencangkokan kornea mata si mayat kepada orang buta bertujuan untuk memelihara masalahat hajiyat. Maka dengan demikian larangan memotong dan mengambil anggota tubuh si mayat dikalahkan oleh kepentingan lain yang lebih besar yaitu kemaslahatan orang-orang yang masih hidup yang sangat memerlukan kornea mata agar mereka bisa hidup sempurna dan dapat menjalankan tugasnya dengan baik sebagai khalifah di muka bumi. ${ }^{43}$

Berkaitan dengan donor kornea mata ini, maka Majelis Ulama Indonesia mengeluarkan fatwa pada tanggal 17 Maret 1989, memutuskan bahwa wasiat orang Islam untuk menyumbangkan kornea mata sesudah ia meninggal adalah halal sepanjang hal itu disetujui dan disaksikan oleh keluarga terdekat. Lalu dilanjutkan fatwa itu bahwa pengoperasian kornea mata harus dilakukan oleh para ahli bedah yang berkompoten الضدرور ات الت

$$
\text { : تبيح الدحضدورات :keadaan darurat dapat membolehkan }
$$

sesuatu yang diharamkan.

Hukum Islam pada dasarnya merupakan ketentuan hukum yang dipahami oleh para ulama dari nash Al-Qur'an dan hadis. Hal itu sangat dipengaruhi oleh situasi dan lingkungan masyarakat tempat para ulama berada. Hukum Islam sebagaimana diketahui bahwa keberadaannya untuk mewujudkan tujuan syariat

\footnotetext{
${ }^{42}$ Ahmad Azhar Basyir, Refleksi atas Persoalan Keislaman Seputar Filsafat, Hukum Politik dan Ekonomi (Cet. IV; Bandung; Mizan, 1996), h. 156.

${ }^{43}$ Iskandar Usman, op.cit., h. 181.

${ }^{44}$ Hasbi Umar, Nalar Fiqh Kontemporer (Cet. I; Jakarta: Gaung Persada, 2007), h. 185.
} 
yaitu untuk merealisasikan kemaslahatan umat manusia. Maka untuk merealisasikan tujuan syariat, hukum itu dapat berubah sesuai dengan keadaan dan perkembangan masyarakat.

Sebagai contoh bahwa Nabi Saw., pada awal perkembangan Islam melarang ziarah kubur karena perbuatan itu dapat mengantar seseorang yang beriman menjadi musyrik. Hal itu disebabkan karena banyak orang yang berziarah kubur meratap sambil berguling-guling dan juga ada yang sampai merobek-robek pakaiannya. Sampai merasa kehilangan semangat hidup dan tidak percaya kepada ketentuan Allah. Bahkan ada yang menganggap bahwa kuburan itu tempat yang keramat, dapat mengabulkan suatu permohonan, dan menjadikan sebagai tempat pengaduan nasib. ${ }^{45}$ Tetapi setelah keadaan berubah, akidah dan keimanan masyarakat sudah kuat, maka Nabi Saw, mengizinkan ziarah kubur, karena dengan ziarah kubur dapat menambah kesadaran beriman bagi seseorang. Adapun hadis yang dijadikan dasar kebolehan ziarah kubur adalah:

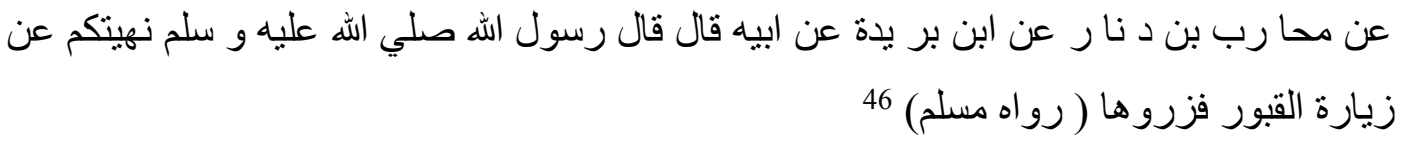

Artinya :

“Dari Muharib bin Dinar dari Ibnu Buraidah dari bapaknya berkata: Nabi saw., bersabda dulu aku melarangmu menziarahi kubur, sekarang ziarahilah.”

Dari uraian tersebut, maka telah jelaslah bahwa keadaan dan perkembangan masyarakat harus dijadikan pertimbangan hukum agar hukum benarbenar dapat berfungsi di tengah-tengah masyarakat. Serta mampu merealisasikan maqashid al-syari'ah yaitu kemaslahatan masyarakat umat untuk menggapai manfaat dan menolak mafsadat.

Menurut Ibnu Qayyim al-Jauziyyah ${ }^{47}$ bahwa hukum itu mengalami perubahan

${ }^{45}$ Iskandar Usman, op.cit., h. 182.

${ }^{46} \mathrm{CD}$ Rom, al-Kutub al-Tis'ah

${ }^{47}$ Mujiono Abdillah, Dialektika Hukum Islam Perubahan Sosial Sebuah Refleksi Sosiologis atas Pemikiran Ibnu Qayyim al-Jauziyyah (Cet. I; Surakarta: Muhammadiyah Press, 2003), h. 74. 
dalam bentuk penundaan atau pembatalan suatu ketentuan hukum tampak selaras dengan panduan dan tujuan hukum Islam, yaitu mewujudkan kemaslahatan umat.

Pembaharuan hukum Islam sebenarnya adalah usaha menetapkan hukum yang dapat menjawab permasalahan dan perkembangan baru yang ditimbulkan oleh ilmu pengetahuan dan teknologi dengan cara menjadikan perkembangan baru tersebut sebagai pertimbangan hukum agar hukum tersebut betul-betul mampu merealisasikan tujuan syariat yang dalam istilah ushul fikih disebut dengan maqashid al-syari'ah. Jadi pembaruan hukum Islam bukanlah berarti usaha menetapkan hukum Islam yang mampu menjawab permasalahan dan perkembangan baru secara sembarangan tanpa berpedoman kepada prinsip-prinsip dan nilai-nilai dasar yang dibawa AlQur'an dan hadis. Akan tetapi pembaruan hukum Islam merupakan usaha menetapkan suatu ketentuan hukum yang sesuai dengan prinsip-prinsip dan nilai-nilai dasar Islam yang dalam pemahamannya dibantu oleh perkembangan baru sebagai suatu pertimbangan dalam menjabarkan prinsip-prinsip dan nilai-nilai dasar tersebut. ${ }^{48}$

Lalu bagaimana relevansi istihsan dengan pembaruan hukum Islam. Istihsan sebagaimana diketahui bahwa berpalingnya seorang mujtahid dari suatu hukum pada suatu masalah kepada hukum yang lain karena ada tinjauan lebih kuat yang menghendaki berpalingnya seorang mujtahid. Maka asas istihsan adalah penetapan hukum yang berbeda dengan kaidah umum, karena keluar dari kaedah umum dapat menghasilkan ketentuan hukum yang lebih sesuai dengan tujuan syariat. Maka berpegang pada istihsan merupakan cara berdalil yang lebih kuat dari pada berpegang pada qiyas. ${ }^{49}$

Maka dengan demikian istihsan sangat relevan dengan pembaruan hukum Islam. Pembaruan hukum Islam bertujuan untuk memelihara tujuan syariat dengan menghasilkan ketentuan-ketentuan hukum yang mampu menjawab permasalahan dan perkembangan baru yang telah ditimbulkan oleh ilmu pengetahuan dan teknologi modern. Sedangkan istihsan merupakan suatu metode

\footnotetext{
${ }^{48}$ Iskandar Usman, op.cit., h. 186.

${ }^{49}$ Ibid., h. 187.
} 
istinbat hukum yang sangat mementingkan pemeliharaan tujuan syariat. Jadi istihsan adalah suatu metode istinbat hukum yang sangat relevan dengan pembaruan hukum Islam. Dengan demikian, antara istihsan dan pembaruan hukum Islam tidak dapat dipisahkan antara satu dengan yang lainnya.

\section{KESIMPULAN}

Dari uraian sebelumnya, maka penulis dapat mengambil beberapa kesimpulan yaitu sebagai berikut :

1. Istihsan merupakan salah satu metode istinbat hukum yang dapat dijadikan hujjah. Dalam fikih Maliki dan Hanafi istihsan mempunyai peranan yang sangat menetukan, karena, banyak hal yang telah diselesaikan dengan metode istihsan dan telah ditetapkan hukumnya. Nampaknya hukum yang ditetapkan dengan istihsan lebih mengayomi dan lebih mampu merealisasikan tujuan syariat. Walaupun metode ini telah ditolak oleh Syafi'iyah karena berbeda pemahamannya dengan Imam Abu Hanifah dan Imam Malik. Akan tetapi jika pemahaman Imam Syafi'i sama dengan Imam Abu Hanifah dan Imam Malik, maka tidak terjadi pertentangan. Sebenarnya mereka berbeda dalam penamaan istilah saja. Karena ulama Syafi'i memandang cara-cara yang ada dalam istihsan, sudah terwakili oleh dalil-dalil muttafaq alaiha, sedangkan ulama Mazhab Hanafi memiliki nama sendiri yaitu istihsan.

2. Pada dasarnya Istihsan mempunyai relevansi dengan pembaruan hukum Islam. Kerelevansian keduanya adalah terletak pada maqashid al-syari'at. Hal ini dapat dilihat bahwa pembaruan hukum Islam bertujuan untuk merealisasikan dan memelihara kemaslahatan umat manusia semaksimal mungkin yang merupakan tujuan syari'at, sedangkan istihsan adalah salah satu metode istinbat hukum yang sangat mengutamakan dan menonjolkan nilai-nilai daripada maqashid al-syari'ah dan selalu berusaha merealisasikan serta memelihara maqashid al-syari'ah yang dimaksud. 


\section{DAFTAR PUSTAKA}

\section{Alquran al-Karim}

Abdillah, Mujiyono. Dialektika Hukum Islam Perubahan Sosial Sebuah Refleksi Sosiologis atas Pemikiran Ibnu Qayyim al-Jauziyyah, Cet.1; Surakarta: 
Muhammadiyah Press, 2003.

Abu Zahrah, Muhammad, Ushul al-Fiqh, diterjemahkan oleh Saefullah Ma'sum, dengan judul Ushul Fiqih, Cet. VI; Jakarta: Pustaka Firdaus, 2000.

Abu Zahrah, Muhammad, Imam Syafi'i, Hayatuhu wa 'asruhu wa fiktuhu ara'uhu wa fiqhuhu, diterjemahkan oleh Abdul Syukur, dengan judul Imam Syafi'i : Biografi dan Pemikirannya dalam Masalah Akidah, Politik dan Fiqh, Cet. II; Jakarta: Lentera, 2005.

Badran, Abu al-'Ainaini Badran. Ushul Fiqh al-Islamiy, Mesir: Mu'assasah Syabab al-Iskandariyah, t.th.

Basyir, Ahmad Azhar. Refleksi atas Persoalan Keislaman Seputar Filsafat, Hukum,Politik dan Ekonomi , Cet. IV; Bandung: Mizan, 1996. CD Room, al-Kutub al-Tisah

Departemen Agama RI, Al-Qur'an dan Terjemahnya, Semarang: Toha Putra, 2002

Departemen Pendidikan Nasional, Kamus Besar bahasa Indonesia, Edisi Keempat, Cet. II; jakarta: Balai Pustaka, 2002

Echol, John M. dan Hassan Shadily, Kamus Inggris Indonesia (Cet. XXV; Jakarta: Gramedia, 2000)

Haq, Hamka. Dialog Pemikiran Islam UjungPandang, Cet. I; Ujung Pandang: Yayasan AHKAM, 1997.

Haroen, Nasrun. Ushul Figh 1, Cet.1; Jakarta: Logos, 1996.

Hassan, Ahmad. Islamic Reserch Institute, diterjemahkan oleh Aqah Garnadi dengan judul Pintu ljtihad sebelum Tertutup, Cet. I; Bandung: Pustaka, 1984.

Hassan, Husain Hamid. Nazariyat al-Maslahat fi al-Fiqh a]-Islamiyah (Mesir: Dar al-Wahdat al-'Arabiyah, t.th)

Hubeis, Umar. dan A. Yazid, Fiqh al-Lughah al-Arabiyah, Jilid II, Cet. IX; Surabaya Pustaka Progresif, 1985.

Khallaf, Abdul Wahab. Ilmu Ushul Fiqh, diterjemahkan oleh Noer Iskandar dengan judul Kaidah-Kaidah Hukum Islam Ilmu Ushul Fiqh, Cet. II; Jakarta: Raja Grafindo, 2000.

Manan, Abdul. Reformasi Hukum Islam di Indonesia (Cet. 1; Jakarta: Raja Grafindo, 2007)

Nata, Abuddin.Masail Fiqhiyah, Cet.I; Jakarta: Kencana,2003. 
Ridha, Muhammad Rasyid. Tafsir al-Manar, Juz I, Kairo: Dar al-Fikr al-'Arbi, 1987.

Syarifuddin, Amir.Ushul Fiqh, Jilid II, Cet. I; Jakarta: Logos, 1999.

Al-Syatibi, Abi Ishaq. al-Muwafaqat fi Ushul al-Syari'ah, Juz I, Cairo: t.th.

Al-Taftazani, Syarh al-Talwik 'ala al-Taudih, Juz 11 (Beirut: Dar al-Kutub alllmiyah, t.th)

Umar, Hasbi. Nalar Fiqih Kontemporer, Cet. I; Jakarta: Gaung Persada, 2007

Usman, Iskandar. Istihsan dan Pembaharuan Hukum Islam, Cet. I; Jakarta: Raja Grafindo: 1994.

Yunus, Mahmud, Kamus Arab Indonesia, Jakarta:Yayasan Penyelenggara. Penterjemah Pentafsiran Alquran, 1990.

Zaidan, Abdul Karim. Al-Wajiz fi Ushul Fiqhi, Beirut: Penerbit Muassasah Risalah, 2002. 